\title{
STAP1 wt Allele
}

National Cancer Institute

\section{Source}

National Cancer Institute. STAP1 wt Allele. NCI Thesaurus. Code C52495.

Human STAP1 wild-type allele is located in the vicinity of $4 q 13.2$ and is approximately 48 $\mathrm{kb}$ in leng th. This allele, which encodes signal-transducing adaptor protein 1 , is involved in the progression of B cell antigen receptor signaling. 